\title{
PENGEMBANGAN KEMAMPUAN PENELITIAN DAN PENULISAN KARYA ILMIAH BAGI GURU MATEMATIKA SMA/SMK MUHAMMADIYAH DI KLATEN DAN SUKOHARJO
}

\author{
Masduki dan Muhammad Noor Kholid \\ Pendidikan Matematika \\ Fakultas Keguruan dan Ilmu Pendidikan \\ Universitas Muhammadiyah Surakarta \\ Email:masduki@ums.ac.id,muhammad.kholid@ums.ac.id
}

\begin{abstract}
ABSTRAK
Tujuan kegiatan pengabdian pada masyarakat ini adalah untuk membimbing guru matematika SMA/SMK Muhammadiyah dalam melakukan kegiatan penelitian dan penulisan karya ilmiah. Kegiatan pengabdian ini dilaksanakan dalam lima tahapan yaitu: 1) Sosialisasi kegiatan penelitian dan penulisan karya ilmiah sebagai bagian dari Pengembangan Keprofesian Berkelanjutan (PKB), 2) memperkuat materi penelitian tindakan kelas (PTK), 3) pembimbingan penyusunan proposal PTK, 4) pembimbingan penulisan laporan penelitian dan karya ilmiah, 5) diseminasi hasil penelitian. Semua tahapan dilaksanakan pada bulan April hingga Oktober 2016. Berdasarkan kegiatan yang telah dilaksanakan disimpulkan: 1) pelatihan dan pendampingan mampu memotivasi para guru untuk mengembangkan kemampuan profesionalisme melalui kegiatan penelitian dan penulisan karya ilmiah, 2) guru mampu melaksanakan kegiatan penelitian tindakan kelas secara berkelompok, 3) guru mampu menulis karya ilmiah dan mempresentasikan dalam forum diseminasi hasil penelitian, 4) terdapat 7 artikel ilmiah hasil penelitian PTK yang ditulis oleh guru sebagai hasil kegiatan pengabdian.
\end{abstract}

Kata kunci: penelitian tindakan kelas, karya ilmiah, pengembangan keprofesian

\begin{abstract}
The community service activities is intended to guide the high schools (SMA/SMK) mathematics teachers of Muhammadiyah in research and writing scientific papers. Service activities carried out in five phases of activities: 1) promoting the activities of research and writing scientific papers as part of the professional development of sustainable (PKB), 2) strengthening research materials class action, 3) mentoring and coaching preparation of research proposals 4) guiding research report writing and article writing scientific publications, and 5) dissemination of research results of teachers. The whole stage activities have been implemented starting in April 2016 to October 2016. Based on the activities that have been conducted conclusion: 1) The training has been done to encourage the Muhammadiyah school teachers to be aware of the need for professional development in research and writing articles scientific, 2) teachers have been able to develop class action research proposals, 3) The teachers have been able to write a scientific article and present at scientific forums such dissemination. 4) It has been resulted 7 articles publication from seven research activities conducted by teachers.
\end{abstract}

Keywords: class action research, scientific work, professional development 


\section{PENDAHULUAN}

Undang-Undang No. 14 Tahun 2005 tentang guru dan dosen, menjelaskan kompetensi adalah seperangkat pengetahuan, keterampilan, danperilakuyangharus dimiliki, dihayati, dan dikuasai oleh guru atau dosen dalam melaksanakan tugas keprofesionalan. Dalam rangka melaksanakan PP. No. 19 Tahun 2005 tentang Standar Nasional Pendidikan, diterbitkan Peraturan Menteri Pendidikan Nasional Republik Indonesia Nomor 16 Tahun 2007 Tentang Standar Kualifikasi Akademik dan Kompetensi Guru. Dalam peraturan tersebut, dijelaskan bahwa Standar kompetensi guru dikembangkan secara utuh dari empat kompetensi utama, yaitu: kompetensi pedagogik, kompetensi kepribadian, kompetensi sosial. kompetensi profesional.

Pengembangan

Keprofesian Berkelanjutan (PKB) adalah pengembangan kompetensi guru yang dilaksanakan sesuai dengan kebutuhan, bertahap, dan berkelanjutan untuk meningkatkan profesionalitasnya. PKB bagi guru mencakup tiga kegiatan yaitu: (1) pengembangan diri; (2) publikasi ilmiah; dan (3) karya inovatif. Tujuan umum PKB adalah untuk meningkatkan kualitas layanan pendidikan di sekolah dalam rangka meningkatkan mutu pendidikan. PKB semakin relevan dengan diterapkannya Peraturan Menteri Pendayagunaan Aparatur Negara dan Reformasi Birokrasi (Menpan \& RB) Nomor 16 Tahun 2009 tentang Jabatan Fungsional Guru dan Angka Kreditnya. Dalam hal ini setiap guru dituntut untuk menyusun rencana pengembangan diri melalui program PKB.

Berdasarkan data Majelis Dikdasmen Kabupaten Klaten terdapat 9 sekolah SMA dan 14 sekolah SMK di bawah naungan persyarikatan Muhammadiyah. Ini berarti sekolah-sekolah Muhammadiyah menempati peran strategis dalam ikut serta mewujudkan tujuan pendidikan nasional. Berkaitan dengan jumlah guru matematika, menurut data terdaftar sebanyak 37 guru matematika yang mengajar di SMA/SMK Muhammadiyah.Berdasarkan statusnya, mayoritas merupakan guru yayasan atau guru tidak tetap (GTT).Melihat strategisnya para guru di sekolah Muhammadiyah dalam ikut serta mencerdaskan kehidupan bangsa maka pengembangan profesionalisme bagi guru-guru sekolah Muhammadiyah menjadi sangat penting untuk dilaksanakan.

Selanjutnya, berdasarkan data Majelis Dikdasmen Kabupaten Sukoharjo tahun 2014 terdapat 7 sekolah SMA dan 4 sekolah SMK yang dikelola oleh Pengurus Daerah Muhammadiyah Kabupaten Sukoharjo. Berkaitan dengan jumlah guru matematika, menurut data dari Majelis Dikdasmen Kabupaten Sukoharjo terdapat 23 guru matematika yang mengajar di SMA dan SMK Muhammadiyah.Profil guru matematika SMA/SMK Muhammadiyah di Sukoharjo juga tidak jauh berbeda dengan guru di Klaten. Sebagian besar merupakan guru tidak tetap (GTT).

Tim pengabdi beserta beberapa dosen di program Studi Pendidikan Matematika FKIP UMS sejak tahun 2011 telah melakukan kegiatan pengabdian pada guru matemaikt SMA/SMK Muhammadiyahse Klaten. Salah satu kegiatan yang telah dilakukan adalah workhop pendampingan penulisan proposal penelitian tindakan kelas (PTK) yang dilakukan selama sehari.Berdasarkan kegiatan yang telah dilakukan diperoleh fakta bahwa para guru masih belum mampu memahami metodologi penelitian yang baik khususnya penelitian tindakan ktan elas (PTK). Para guru masih kesulitan dalam menentukan metode penelitian seperti apa yang harus digunakan untuk memecahkan permasalahan yang dihadapi di kelas. Selain itu guru juga mengalami kesulitan menyusun suatu proposal penelitian yang baik yang sesuai dengan kaidah-kaidah atau format suatu proposal maupun kaidah kebahasaan yang tepat.

Berdasarkan wawancara dengan sebagian guru diperoleh informasi bahwa mereka belum pernah melakukan kegiatan penelitian karena berbagai hal, antara lain: (1) mayoritas guru mendapatkan jam mengajar lebih dari 30 jam pelajaran matematika setiap 
minggu. Apabila ditambah dengan pekerjaan administrasi guru, rata-rata guru matematika beraktifitas 6-7 jam per hari atau 36-42 jam per minggu. Dengan kondisi seperti ini para guru merasa tidak mempunyai waktu lagi untuk melakukan kegiatan pengembangan diri termasuk kegiatan penelitian; (2) para guru menganggap kegiatan penelitian merupakan kegiatan yang cukup sulit dan membutuhkan waktu yang panjang sehingga para guru malas melakukannya. Kesulitan guru terutama disebabkan lemahnya pengetahuan tentang metodologi penelitian khususnya penelitian tindakan kelas.Lemahnya pengetahuan para guru tentang metodologi penelitian menyebabkan kesulitan dalam menyusun suatu proposal untuk kegiatan penelitian; dan (3) lemahnya dukungan dari lembaga seperti sekolah maupun Diknas kepada guru untuk melakukan kegiatan penelitian.Jarang ada kegiatan-kegiatan pelatihan penulisan proposal penelitian dan karya ilmiah atau kompetisi hasil-hasil penelitian para guru.Kalaupun ada guru yang melakukan penelitian atau penulisan karya ilmiah hal itu semata-mata untuk memenuhi syarat kenaikan jabatan.Hal ini mengakibatkan kurang termotivasinya guru dalam melakukan kegiatan penelitian dan penulisan karya ilmiah.

Berdasarkan kondisi sebagaimana diuraikan di atas, dipandang perlu untuk mengembangkan profesionalisme khususnya dalam bidang penelitian dan penulisan karya ilmiah bagi guru-guru SMA/SMK Muhammadiyah khususnya di Kabupaten Klaten dan Sukoharjo.Pengembangan kemampuan penelitian dianggap penting karena mendorong guru untuk menggali permasalahan-permasalahan yang muncul dalam pembelajaran di kelas yang selanjutnya tertantang untuk merumuskan langkah-langkah penyelesaian menggunakan prosedur-prosedur penelitian yang telah diakui seperti PTK. Dengan melaksanakan penelitian berarti guru telah berusaha untuk memperbaiki kualitas pembelajaran di kelas, yang implikasinya akan meningkatkan kualitas pendidikan bagi siswa.
METODE PELAKSANAAN

\section{PENGABDIAN}

Untuk mengatasi berbagai permasalahan yang muncul pada mitra maka ditawarkan solusi dengan memberikan kegiatan pendampingan dan pembimbingan dalam pengembangan kemampuan penelitian dan penulisan karya ilmiah dengan tahapan kegiatan sebagai berikut.

1. Pada tahap awal, kegiatan ini dilaksanakan dengan memberikan motivasi kepada para guru tentang pentingnya kegiatan penelitian dan penulisan karya ilmiah bagi pengembangan profesi guru yang tidak hanya berfungsi administratif sebagai angka kredit untuk kenaikan jabatan tetapi lebih dari itu sebagai sarana untuk mengembangkan kompetensi guru serta meningkatkan kualitas pembelajaran di kelas atau pendidikan secara umum. Dengan kegiatan ini diharapkan tumbuh semangat para guru untuk melaksanakan kegiatan penelitian dan penulisan karya ilmiah sebagai upaya pengembangan diri bagi guru. Bentuk kegiatan ini adalah sosialisasi PKB, penelitian, dan penulisan karya ilmiah.

2. Tahap kedua adalah penguatan materi metodologi penelitian khususnya penelitian tindakan kelas serta teknik penulisan karya ilmiah yang baik. Bentuk kegiatan ini adalah diskusi mengenai jenis-jenis penelitian, baik penelitian kuantitatif, kualitatif, maupun penelitian tindakan kelas. Namun para guru diarahkan untuk lebih memfokuskan diri pada penelitian tindakan kelas sebagai jenis penelitian yang sesuai bagi guru untuk peningkatan kualitas pembelajaran di kelas. Dengan kegiatan ini diharapkan para guru memiliki pengetahuan yang memadai sebagai bekal untuk melaksanakan kegiatan penelitian.

3. Tahap berikutnya adalah pendampingan dan pembimbingan penyusunan proposal penelitian. Kegiatan ini dilaksanakan dalam bentuk workshop 
penulisan proposal penelitian dimana tim pengabdian melakukan pembimbingan kepada para guru. Pembimbingan dimulai sejak mengidentifikasi permasalahan pembelajaran di kelas, perumusan permasalahan, penentuan solusi permasalahan pembelajaran, penulisan proposal penelitian, hingga pengembangan instrumen penelitian. Dalam kegiatan ini diharapkan setiap sekolah terdapat sebuah proposal penelitian yang akan dilaksanakan oleh satu tim peneliti guru matematika. Manfaat dibentuknya tim peneliti selain memudahkan dalam pelaksanaan kegiatan penelitian juga untuk mendorong para guru untuk senantiasa bekerjasama dalam memecahkan berbagai permasalahan yang muncul dalam pembelajaran.

4. Tahap keempat adalah pedampingan dan pembimbingan penulisan laporan penelitian dan penulisan artikel publikasi ilmiah. Pada tahap ini, tim pengabdian berfungsi sebagai menuliskan hasil penelitiannya dalam bentuk laporan penelitian dan membuat artikel publikasi ilmiah. Laporan penelitian dan artikel publikasi ilmiah yang telah ditulis selanjutnya didiskusikan dengan tim pengabdian untuk mendapat masukan atau saran perbaikan sehingga diperoleh laporan penelitian dan artikel publikasi yang baik.

5. Tahap kelima adalah diseminasi hasil penelitian tindakan kelas. Pada kegiatan ini setiap tim penelitian mempresentasikan hasil penelitiannya dalam forum ilmiah yaitu diseminasi hasil penelitian

\section{HASIL DAN PEMBAHASAN}

Kegiatan pengabdian di Kabupaten Klaten dilakukan dengan Dikdasmen PDM Kabupaten Klaten yang selanjutnya di delegasikan kepada Musyawarah Kerja Kepala Sekolah (MKKS) SMA/SMK Muhammadiyah.Sedangkan di Sukoharjo dikelola oleh tim pengabdi secara langsung dan dilaksanakan di Kampus Universitas Muhammadiyah Surakarta. Rincian kegiatan yang telah dilakukan sebagai berikut.

\section{Tahap Pertama: Sosialisasi Pengembangan Keprofesian Berkelanjutan (PKB).}

Kegiatan sosialisasi PKB untuk guru matematika SMA/SMK Muhammadiyah di Kabupaten Klaten dilaksanakan pada hari Sabtu, 23 April 2016 bertempat di SMA Muhammadiyah I Klaten. Kegiatan ini diikuti oleh 33 orang guru matematika SMA/SMK Muhammadiyah di Klaten serta dihadiri oleh pengurus Musyawarah Kerja Kepala Sekolah (MKKS) SLTA Muhammadiyah di Klaten. Narasumber yang memberikan materi tentang PKB adalah Drs. Muhroji, M.Si, dosen program studi Pendidikan Guru Sekolah Dasar (PGSD) UMS yang merupakan salah satu pengelola program Pendidikan dan Latihan Profesi Guru (PLPG) di UMS.Sedangkan kegiatan di Sukoharjo diselenggarakn tanggal 28 Mei 2016 di Universitas Muhammadiyah Surakarta yang diikuti 21 orang guru. Narasumber untuk sosialisasi PKB di Sukoaharjo adalah Masduki, M.Si.

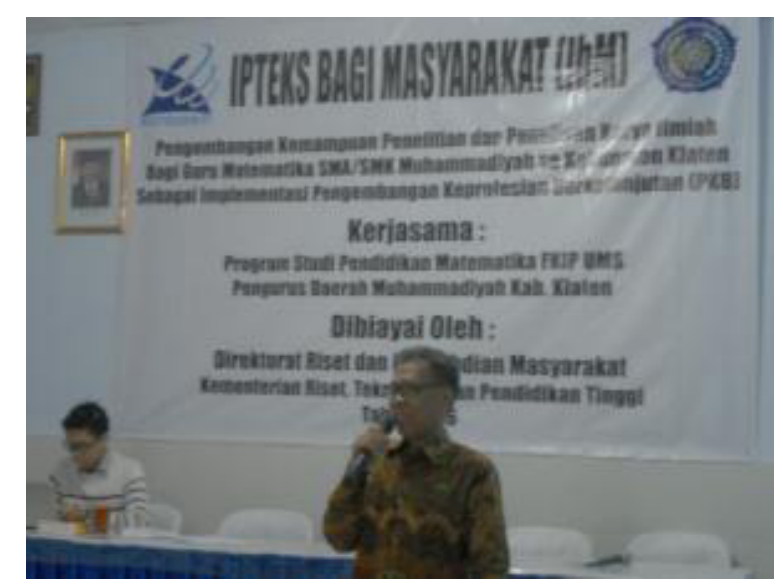

Gambar 1. Penyampaian Materi PKB oleh Narasumber

Pada kegiatan ini, $\begin{array}{r}\text { narasumber } \\ \text { perlunya }\end{array}$
menyampaikan tentang
guru mengembangkan
profesionalismenya, khususnya guru
bersertifikasi, melalui berbagai aktifitas
sesuaidengan peraturan yang telah ditentukan
oleh pemerintah. Setelah narasumber


menyampaikan materi, dilakukan diskusi atau tanya jawab antara narasumber dengan guru.

Setelah kegiatan sosialisasi PKB guru-guru menjadi memahami perlunya PKB untuk meningkatkan kemampuan profesionalismenya. Selain itu guru juga lebih memahami bahwa kegiatan penelitian dan penulisan karya ilmiah (artikel publikasi) merupakan salah satu kegiatan pengembangan kemampuan profesionalisme guru terutama guru yang telah bersertifikasi. Namun dari diskusi yang dilakukan, tampak bahwa para guru masih memikirkan apa dampak secara langsung bagi guru ketika melakukan peneliti khususnya untuk kenaikan pangkat. Apalagi sebagian besar guru sekolah Muhammadiyah adalah guru Guru Tetap (GT) dan Guru Tidak Tetap (GTT) yang tidak memerlukan untuk kenaikan pangkat.

\section{Tahap Kedua: Penguatan Materi PTK dan Penyusunan Draft PTK}

Kegiatan tahap kedua yaitu penguatan materi penelitian tindakan kelas (PTK) yang dilaksanakan hari Sabtu, 23 April 2016 setelah kegiatan sosialisasi PKB.Sedangkan kegiatan di Sukoharjo diselenggarakan tanggal 28 Mei 2016.Narasumber yang menyampaikan materi adalah Rita Pramujiyanti Khotimah, S.Si., M.Si., dosen program studi Pendidikan Matematika FKIP UMS yang juga merupakan salah satu seorang instruktur PLPG di UMS. Narasumber menyajikan materi tentang Penelitian Tindakan Kelas (PTK) berbasis Lesson Study (LS) dimana kegiatan penelitian dilaksanakan secara kolaboratif antar guru mulai dari perencanaan, pelaksanaan, observasi, hingga refleksi. Setelah penyampaian materi oleh Narasumber, kegiatan dilanjutkan dengan diskusi atau tanya jawab untuk memperdalam materi yang telah disajikan oleh narasumber. Kemudian para guru, dalam kelompok, membuat draft proposal penelitian tindakan kelas dengan dipandu oleh tim pengabdi. Selanjutnya draft yang telah disusun digunakan sebagai kerangka acuan untuk menyusun proposal yang sesungguhnya.
Kegiatan ini menghasilkan draft proposal yang berupa poin-poin utama yang akan menjadi kerangka dalam penyusunan proposal secara lebih lengkap. Guru secara berkelompok diminta menyusun proposal PTK secara lebih lengkap sebagai bahan diskusi untuk kegiatan tahap ketiga yaitu pembimbingan penyusunan proposal PTK.

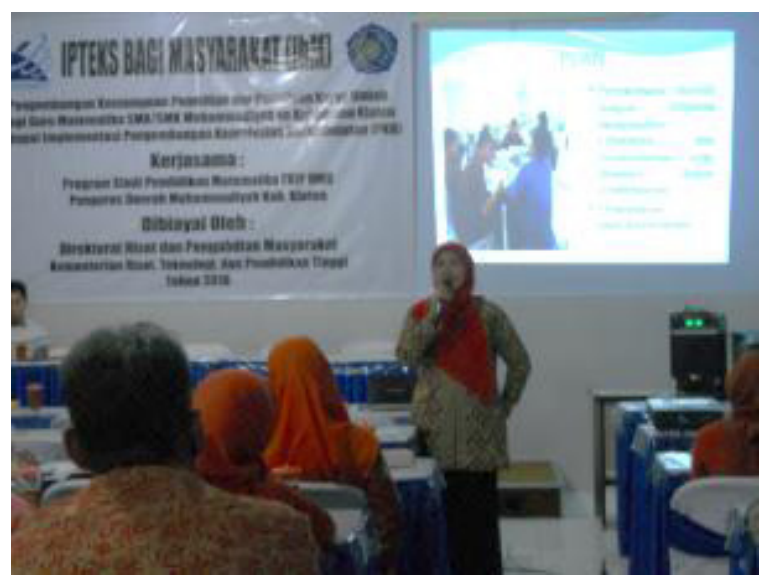

Gambar 2. Narasumber Menyampaikan Materi PTK

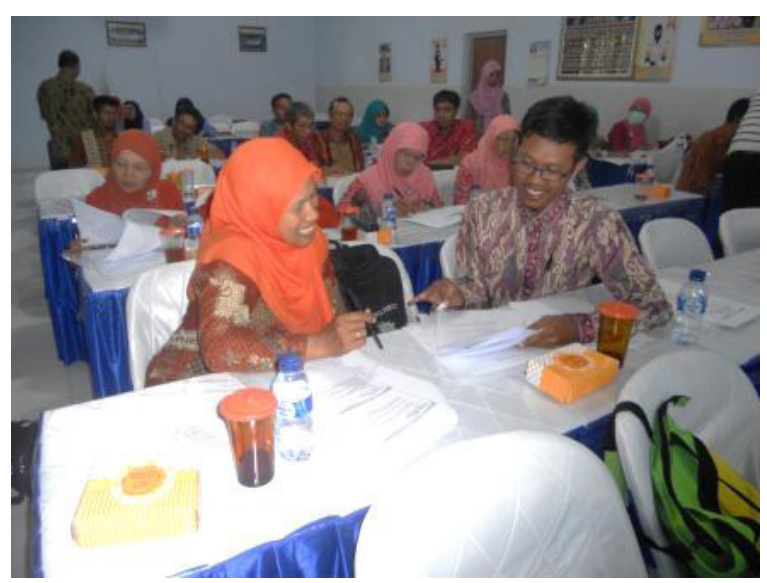

Gambar 3. Guru Berdiskusi Menyusun Draft Proposal PTK

\section{Tahap Ketiga; Pembimbingan Penyusunan Proposal PTK}

Tahap ketiga dilaksanakan pada hari Rabu, 18 Mei 2016 bertempat di SMA Muhammadiyah I Klaten. Kegiatan tahap ketiga dihadiri oleh 32 orang guru matematika SMA/SMK Muhammadiyah di Klaten.Sedangkan untuk guru di Sukoharjo dilaksanakan tanggal 31 Agustus 2016. Pada tahap ini, kegiatan yang dilaksanakan 
adalah pembimbingan penyusunan proposal PTK. Dalam kegiatan ini proposal yang telah disusun oleh tim guru dalam satu sekolah didiskusikan dengan tim pengabdi untuk mendapatkan masukan atau koreksi perbaikan. Selanjutnya para guru melakukan perbaikan proposal sesuai dengan hasil masukan dari tim pengabdi. Dokumentasi kegiatan tahap ketiga disajikan sebagai berikut:

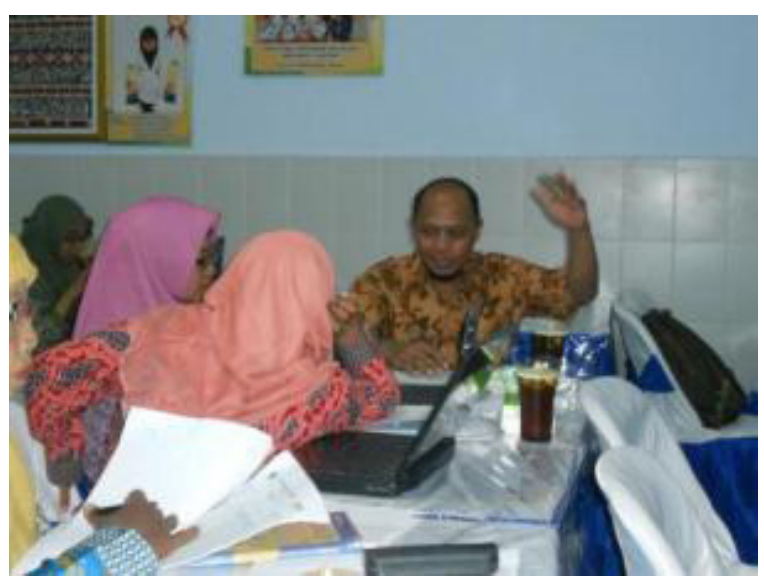

Gambar 4. Pembimbingan Proposal PTK oleh Tim Pengabdi

Setelah kegiatan tahap ketiga, guru memperoleh proposal PTK yang lebih baik daripada draft yang sebelumnya telah disusun.Namun berdasarkan hasil pembimbingan, para guru masih perlu memperbaiki proposal PTK sehingga menjadi layak untuk dilanjutkan pada kegiatan penelitian. Kelemahan proposal yang disusun oleh para guru sebagian besar adalah masih kurang lengkapnya instrumeninstrumen untuk penelitian antara lain istrumen pengamatan, instrument penilaian, serta perangkat pembelajaran yang sesuai dengan model/strategi yang digunakan untuk penelitian. Selanjutnya, para guru diminta untuk memperbaiki kembali proposal yang telah diperoleh dalam kegiatan tahap ketiga sehingga menjadi layak untuk dijadikan sebagai proposal penelitian PTK.

Setelah mengikuti kegiatan tahap ketiga ini, para guru selanjutnya melaksanakan kegiatan penelitian di sekolah masingmasing. Berdasarkan proposal PTK yang telah disusun, terdapat tujuh kelompok PTK yang akan melaksanakan kegiatan penelitian. Diantara ketujuh kelompok tersebut, empat sekolah merupakan tim penelitian pada sekolah yang sama, sedangkan tiga kelompok yang lain merupakan gabungan dari 2-3 sekolah. Hal ini menunjukkan bahwa para guru dapat saling berkolaborasi dalam melaksanakan kegiatan penelitian.

\section{Tahap keempat: Pembimbingan Penyusunan Draft Laporan Penelitian dan Artikel Publikasi}

Kegiatan tahap keempat yaitu pembimbingan penyusunan draft laporan dan artikel publikasi hasil penelitian dilaksanakan pada hari Sabtu, 10 September 2016 di SMA Muhammadiyah I Klaten.Kegiatan ini diikuti oleh 21 orang guru matematika SMA/SMK Muhammadiyah di Klaten. Pada kegiatan tahap keempat ini tim pengabdi mengawali diskusi dengan menyampaikan sistematika laporan penelitian PTK serta contoh format penulisan artikel publikasi ilmiah hasil penelitian. Selanjutnya, para guru secara berkelompok dibimbing untuk menyusun draft laporan penelitian serta artikel publikasi. Dokumentasi kegiatan tahap keempat disajikan pada Gambar berikut:

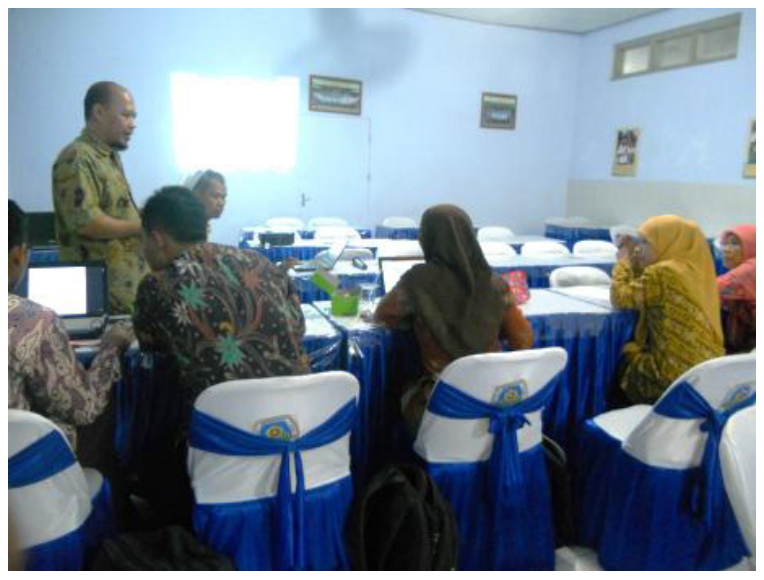

Gambar 5. Pembimbingan Penyusunan Draft Laporan Penelitian

Berdasarkan kegiatan yang telah dilakukan, para guru yang sebelumnya kebingungan dalam menuliskan hasil penelitian baik dalam bentuk laporan maupun 
artikel publikasi, mampu menyusun draft laporan dan artikel hasil penelitian sesuai dengan sistematika yang berlaku. Guru juga mampu mengolah dan melakukan analisis terhadap hasil penelitian yang diperoleh. Pada kegiatan berikutnya, para guru akan menyajikan hasil penelitian yang telah dilakukan dalam bentuk diseminasi hasil penelitian PTK.

\section{Tahap kelima: Diseminasi Hasil Penelitian PTK}

Kegiatan diseminasi hasil penelitian PTK dilaksanakan pada hari Sabtu, 22 Oktober 2016 di SMA Muhammadiyah I Klaten.Kegiatan ini bertujuan agar para guru mampu mempresentasikan hasil penelitian yang telah dilakukan dalam forum-forum seminar atau diskusi.Kegiatan ini diikuti oleh 23 guru matematika SMA/SMK dan 5 orang guru matematika SMP Muhammadiyah di Klaten. Pada kegiatan ini, diawali dengan penyampaian materi "Pembelajaran Matematika Realistik: Suatu alternatif pendekatan pembelajaran" yang disajikan oleh Masduki, M.Si. Selanjutnya setiap tim penelitian menyampaikan hasil penelitian yang telah dilakukan di hadapan para peserta. Setiap selesai pemaparan, dilakukan diskusi untuk lebih mendalami hasil penelitian yang telah dilakukan oleh guru.Dokumentasi kegiatan tahap kelima disajikan sebagai berikut.

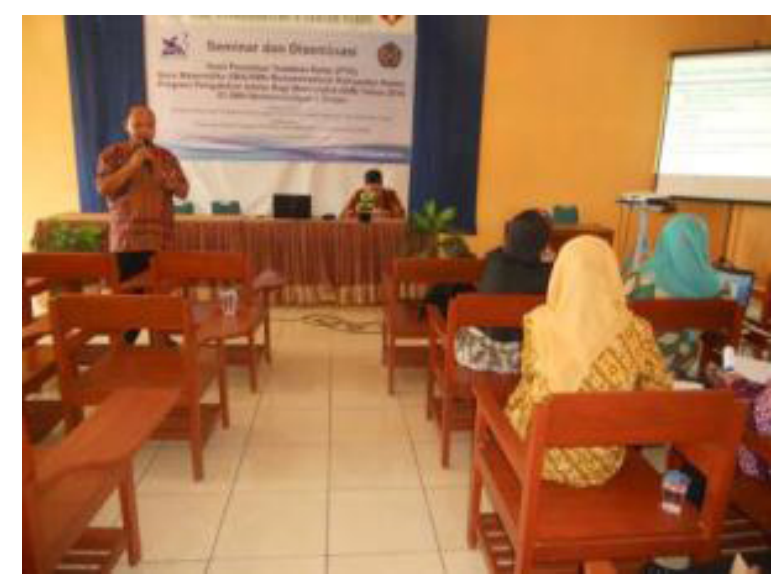

Gambar 6. Pemateri Pembelajaran Matematika Realistik

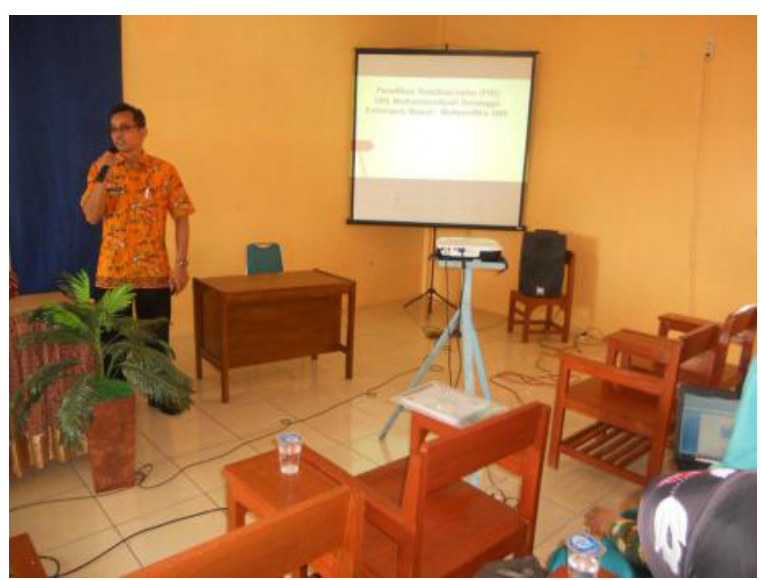

Gambar 7. Guru Mempresentasikan Hasil Penelitian PTK

Dalam kegiatan diseminasi terdapat tujuh kelompok penelitian yang mempresentasikan hasil penelitiannya.Tujuh kelompok tersebut melibatkan 12 sekolah dan 20 orang guru. Hal ini menunjukkan bahwa kegiatan pengabdian IbM telah berhasil mendorong para guru bekerjasama secara kolaboratif dalam melaksanakan kegiatan penelitian dan penulisan artikel ilmiah.

\section{KESIMPULAN}

Tim pengabdi telah melaksanakan program kegiatan IbM sesuai dengan tahapan pelaksanaan yang direncanakan. Berdasarkan kegiatan yang telah dilaksanakan dapat disimpulkan sebagai berikut:

1. Kegiatan pelatihan yang telah dilakukan mampu mendorong para guru sekolah Muhammadiyah untuk menyadari perlunya pengembangan profesionalisme guru dengan jalan melaksanakan kegiatan penelitian dan penulisan artikel ilmiah.

2. Para guru telah mampu menyusun proposal PTK yang siap diimplementasikan dalam penelitian di kelas setelah mengikuti kegiatankegiatan yang diprogramkan oleh tim pengabdi.

3. Para guru telah mampu menulis artikel ilmiah dan menyajikannya pada forum ilmiah seperti diseminasi.

4. Telah diperoleh 7 artikel publikasi yang melibatkan 20 guru dan 12 sekolah 
berasal dari tujuh kegiatan penelitian yang dilakukan oleh para guru dan telah dipresentasikan dalam kegiatan diseminasi hasil penelitian PTK

Selanjutnya tim pengabdi memberikan saran kepada instansi terkait berkaitan dengan pengembangan PKB khususnya pengembangan kemampuan penelitian dan penulisan karya ilmiah guru.

1. Perlu sosialisasi dan motivasi khususnya dari para pemangku jabatan (kepala sekolah, Majelis Dikdasmen PDM, Diknas) untuk mendorong guru mengembangkan profesionalisme guru melalui program PKB.

2. Perlu dukungan dari para pemangku jabatan khususnya dukungan finansial untuk mendorong para guru melaksanakan kegiatan penelitian dan publikasi ilmiah.
3. Perlu kerjasama antar lembaga, misal sekolah dan perguruan tinggi, untuk meningkatkan kemampuan profesi guru, khususnya guru pada sekolah-sekolah Muhammadiyah.

\section{PERSANTUNAN}

Tim pengabdi mengucapkan terimakasih kepada Direktorat Riset dan Pengabdian Masyarakat (DRPM) Kementerian Riset, Teknologi, dan Pendidikan Tinggi (Kemristekdikti) yang telah mendanai kegiatan pengabdian ini dalam program pengabdian Ipteks Bagi Masyarakat (IbM) dengan nomor perjanjian pelaksanaan: 006/SP2H/LT/DRPM/II/2016, tanggal 17 Februari 2016. Tim pengabdi juga mengucapkan terimakasih kepada Lembaga Penelitian dan Pengabdian Masyarakat UMS yang telah membantu dalam pengelolaan administrasi kegiatan pengabdian ini

\section{DAFTAR PUSTAKA}

Peraturan Pemerintah No. 19 Tahun 2005 tentang Standar Nasional Pendidikan

Peraturan Menteri Pendidikan Nasional Republik Indonesia Nomor 16 Tahun 2007 Tentang Standar Kualifikasi Akademik dan Kompetensi Guru

Peraturan Menteri Pendayagunaan Aparatur Negara dan Reformasi Birokrasi (Menpan \& RB) Nomor 16 Tahun 2009 tentang Jabatan Fungsional Guru dan Angka Kreditnya

Subadi, Tjipto., Khotimah, Rita P., dan SutarniSri. 2012. Model Pembinaan Pendidik Profesional (Suatu Penelitian dengan Pendekatan Lesson Study pada Guru-Guru Sekolah Muhammadiyah Kabupaten Sukoharjo). Laporan Penelitian tidak diterbitkan, Penelitian Unggulan Perguruan Tinggi (PUPT) Tahun I, LPPM UMS.

-----------. 2013. Model Pembinaan Pendidik Profesional (Suatu Penelitian dengan Pendekatan Lesson Study pada Guru-Guru Sekolah Muhammadiyah Kabupaten Sukoharjo). Laporan Penelitian tidak diterbitkan, Penelitian Unggulan Perguruan Tinggi (PUPT) Tahun II, LPPM UMS.

Undang-Undang Nomor 20 Tahun 2003 Tentang Sistem Pendidikan Nasional

Undang-Undang Nomor 14 Tahun 2005 Tentang Guru dan Dosen 